\title{
New evidence of relative performance evaluation (RPE) in UK Chief Executive realised incentive compensation
}

\author{
Mark A. Farmer ${ }^{\mathrm{a}^{*}}$, George Alexandrou ${ }^{\mathrm{a} 1}$ and Stuart Archbold ${ }^{\mathrm{a} 2}$. \\ ${ }^{a}$ Kingston Business School, Kingston Hill, Kingston-Upon-Thames, KT2 7LB, United Kingdom
}

\begin{abstract}
In this paper we investigate the association between corporate performance and CEO pay using a panel of 204 large UK companies, between 2003 and 2007. The major and novel contribution of the paper is the focus on payouts from performance-stock option and performance-share plans. We demonstrate that it is crucial to distinguish between the different elements of executive pay and the different performance conditions that attach to those elements if we are to establish a comprehensive understanding of the pay-forperformance relationship. Using fixed-effects regressions, we provide new and convincing evidence that performance-realised short-term pay is determined relative to FTSE-350 market performance and performance-realised long-term pay is determined relative to FTSE-350 sector performance.
\end{abstract}

Key words: chief executive compensation, corporate performance, agency theory, relative performance evaluation theory.

JEL classification: G30, M48.

\footnotetext{
* Corresponding author. Tel.: +44 2084175508

E-mail addresses: m.a.farmer@kingston.ac.uk (M.A. Farmer), g.alexandrou@kingston.ac.uk (G. Alexandrou) s.archbold@kingston.ac.uk (S. Archbold)

${ }^{1}$ Tel.: +44 2084175209

${ }^{2}$ Tel.: +442084175435
} 


\section{Introduction}

Corporate executive remuneration is a highly controversial issue in most developed capitalist economies, one that attracts the attention of academic researchers, investors, investor organisations, legislators, and media commentators. Although the focus of these groups has many similarities, there are often important differences of substance: in particular, the media and politicians tend to focus attention on the scale of executive pay, whereas for academics, investors and legislators the central concern or focus tends to be on whether executive compensation is linked to corporate performance.

Since the publication of the Cadbury Report (1992), there have been a number of important corporate governance milestones in the process of ensuring greater transparency and improved accountability of UK executives to their shareholders. These milestones include: the Cadbury Report (1992), the Greenbury Report (1995), which emphasized the need to tie executive remuneration incentives to 'more challenging performance criteria', and the Hampel Report (1998). The Combined Code on corporate governance was first issued in 1998 by the London Stock Exchange and effectively replaced Cadbury, Greenbury and Hampel. Following these reports, which urged transparency and self-regulation, the UK government saw fit to enact legislative provisions in relation to executive remuneration and Parliament passed the Directors' Remuneration Report Regulations (2002). In the wake of this legislation, there have been further major corporate governance milestones that deal inter alia with executive remuneration, the Higgs Report (2003) and revisions to the Combined Code $(2003,2006,2008,2010)$.

Despite these reports, the 2002 legislation and other changes in corporate governance, investors and investor organisations, such as the Association of British Insurers and the National Association of Pension Funds, remain concerned that executives continue to be rewarded excessively, particularly when company performance is poor. The global financial crisis of 2008-09, combined with media criticism of so-called greedy bank executives being paid extravagant salaries and bonuses whilst overseeing bank failure and distress on an almost unprecedented scale, has further intensified the disquiet over executive compensation.

In the academic sphere, despite a substantial empirical literature, largely situated in the US and the UK, the existence, but more particularly the strength of the relationship between corporate performance and executive compensation continues to be an unresolved issue 
(see, for example, Bruce et al. (2005) for a review of the issues and evidence from a UK perspective).

The purpose of this paper is to empirically examine how corporate performance influences chief executives pay in UK public listed companies. Specifically to identify evidence of relative performance evaluation in elements of chief executive pay; following the recommendation in the Combine Code (2003) to link long-term incentive compensation to relative firm performance.

According to principal-agent theory executive compensation should be related to the success of the firm via an incentive contract which is designed to ensure that executives are acting in the interests of shareholders. However, since the executive is risk-averse and company performance is assumed not simply to be influenced by executive effort but also by random shocks, an incentive contract that is purely tied to absolute company performance may not be optimal (Aggarwal and Samwick, 1999). An incentive contract is thought not to be optimal if firm performance is correlated with market performance since an executive contract based only on absolute firm return will reward or penalise the executive for general market movement (Câmara, 2001). A more efficient compensation contract ought to exclude the effects of market wide random or exogenous shocks which are outside the control of the executive.

A group of companies exposed to the same random shocks are said to face similar market risk. Holmström (1982) and Holmström and Milgrom (1987) propose that a compensation contract reflective of an agent's own performance and the performance of other agents facing similar market risk will be more efficient. This is known as the relative performance evaluation (RPE) hypothesis. RPE theory suggests that the agent's performance is determined by a comparison to the performance of other agents, a peer group, and as a consequence executive compensation will also be relative (Holmström, 1982). According to agency theory and relative performance evaluation theory managers should be remunerated on a basis that excludes market-wide performance (systematic risk) but the empirical research does not always find this to be the case (Rajgopal et al., 2006). A relative performance measure that evaluates the firm's performance compared to a group of firms in the same industry or relative to the market as a whole will to some extent protect the executive from the vagaries of the stock market (Gibbons and Murphy, 1990). The literature describes two forms of RPE. The strong form of the hypothesis completely filters out 
market-wide performance whereas the weak form of the hypothesis only partially filters out market-wide performance and therefore includes elements of systematic and unsystematic performance (Rajgopal et al., 2006). RPE theory predicts a significant negative association between peer group performance and executive compensation after controlling for individual firm performance.

The association between peer group performance and executive compensation has been addressed in a number of pay-for-performance studies. There is some evidence of RPE in US studies, typically finding support for the weak form of the RPE hypothesis, and very little support for either form of the RPE hypothesis in the UK applied literature. The latest research to investigate RPE includes a US based study by Albuquerque (2009) and a UK based study by Liu and Stark (2009). Using a large longitudinal sample of over 2000 firms between 1992 and 2005, Albuquerque (2009), finds strong evidence for both forms of the RPE hypothesis when performance is measured using average stock returns but no evidence for average return on assets. Liu and Stark (2009) using a longitudinal sample between 1971 to 1998 , find some evidence to support the week form of the RPE hypothesis when using an accounting-based performance measure, average industry return on book value, but no evidence for average cash stock market industry return. Otherwise the evidence on RPE in UK chief executive compensation is for the most part not convincing. Other UK studies, using various measures of relative firm performance, find no significant support for RPE (Benito and Conyon, 1999; Conyon, 1998; Conyon, 1997; Cosh and Hughes, 1997; Main et al., 1996; Conyon and Leech, 1994).

Relative performance evaluation is an important question that recent UK studies, with the exception of Liu and Stark (2009) ${ }^{1}$, have failed to address. The absence of recent UK research in this area is puzzling given the improved transparency and therefore granularity of compensation data to perform more intricate tests. As well as the theoretical arguments there is also an expectation on firms to link executive remuneration to relative performance since the publication of the Greenbury report (1995, p.17) advocated the use of RPE in longterm incentive schemes. The Association of British Insurers (ABI) also expects firms to use RPE with respect to long-term incentive arrangements (Liu and Stark, 2009). Further, the Combined Code $(2003,2006)$ expects firms to link payouts or grants of long-term incentives to relative firm performance.

\footnotetext{
${ }^{1}$ The recent study by Liu and Stark (2009) uses a dataset ending in 1998.
} 
In this paper we assert that one of the major reasons for not finding evidence of RPE in UK executive compensation is the considerable variety of measures of executive remuneration to be found in the extant literature. In an extensive review of the executive compensation literature, Devers et al. (2007) highlight the use of inconsistent compensation measures and suggest that future research needs to provide greater justification for the pay constructs and measures employed. Filatotchev et al. (2007) suggests research distinguish between 'potential' and 'actual' rewards. We do precisely that in this paper and make a distinction between the different concepts and measures of executive compensation in the UK in ways that previous studies have not done. We are aided in this by the introduction of the Directors' Remuneration Report Regulations 2002, which impose disclosure requirements on remuneration reports that allow us to hand collect data that would not have been readily available prior to 2002 and are not available on financial databases.

We begin by defining chief executive compensation in terms of performance-realised pay. That is the remunerative rewards that executives do receive based on actual performance. Next, we recognise that total performance-realised pay consists of three key elements and we incorporate these in our study. First, basic pay, which is paid in cash. Second, short-term bonus, which is most often based on a single year's corporate accounting performance, paid in cash, but sometimes with a mix of cash and shares (with one or both elements perhaps deferred). Third, a long-term incentive, based on longer term absolute and/or relative corporate performance measured against a peer group and paid in shares or options.

Finally, we address explicitly the different performance requirements for the different elements that make up total executive compensation and in particular the relative performance requirements of long-term incentives. We do this by separating different elements of pay and conducting separate regression analyses on these elements.

Using an unbalanced panel of Chief Executive Officers (CEO) drawn from 204 of the largest, non-financial UK companies, we provide statistically significant evidence that shortterm performance-realised pay is positively related with corporate performance and negatively with market performance. Further, we also provide significant evidence that long-term performance-realised pay is positively related with corporate performance and negatively with industry performance. In common with previous studies, basic pay is significantly and positively related to company size but also somewhat determined relative to peer group performance. Therefore, unlike previous studies, we find a strong relationship 
between peer group performance and the compensation earned by CEOs. These findings provide robust evidence that is consistent with the principal-agent framework of executive pay and corporate performance.

The rest of the paper is organised as follows. The next section, section 2, provides a brief review of the literature and develops the hypotheses to be tested. Section 3 deals with the research methods employed and the data. Section 4 presents the results of the regression analyses and section 5 provides concluding remarks.

\section{Literature and hypothesis development}

In this section we develop the specific hypotheses to be tested. We begin by considering the measurement issues associated with executive compensation. We then consider firm size which many studies have reported to be the major determinant of executive compensation. This is followed by the measurement issues involved in corporate performance and the specific hypotheses to be tested. A summary of the hypotheses is shown in Figure 1.

It is put forward that the empirical finding of only a weak relationship between firm performance and executive pay and the limited evidence of relative performance evaluation is a reflection of the measurement of the compensation variable used by researchers. For example, studies have combined basic pay (BP), performance-contingent pay (PCP) and performance-realised pay (PRP) into a single construct of executive compensation (for example, Gregory-Smith, 2009; Kuang and Qin, 2009). In contrast, this study disentangles the three types of executive remuneration so to treat realised incentive payments as distinct from maximum incentive opportunities. With the intention to gain a more insightful understanding of the association between corporate performance and chief executive pay, compensation is expressed in terms of BP and PRP. The chief executive compensation construct is then further divided into its various elements: BP; short-term PRP, long-term PRP and total PRP. The precise measurement specification for each pay element is described in detail in section 3. 


\subsection{Compensation measurement}

The structure of executive compensation is complex and continually changing to reflect best corporate governance practice and market norms. In an analysis of US chief executive compensation data Towers Perrin (2008) report that in 2004 stock options represented 38\% of CEO pay. By 2008 the proportion of stock options had fallen to $23 \%$ of pay, while, performance share plans increased from $8 \%$ of the pay mix to $21 \%$. In the UK the nature of stock option plans has changed remarkably due to changes in corporate governance guidelines. For example, it is now regarded as 'poor' practice to issue discounted stock options (Combined Code, 2003). There are also different pay practices between countries. For example, according to the Hay Group's 2006 Top Executive Compensation study, US executive stock options are normally issued without performance conditions (time-vested options), while in the UK the vesting of executive stock options are virtually always subject to performance criteria (performance-options). One of the difficulties researchers encounter investigating the link between corporate performance and executive pay is finding appropriate measures of the different elements that constitute total compensation.

Basic pay is paid in cash with no performance restrictions or incentive component. As Buck et al. (2003) point out, in a pure principal-agent model of executive incentives, shareholder-executive interests might be best aligned by paying executives only with shares. However, this is to ignore the differences in risk aversion and the different opportunities to diversify finance and human capital. To overcome these problems of executive risk aversion a substantial base pay is paid, both to attract and to retain talented executives.

A short-term incentive is typically offered to executives based on short-term corporate performance. The incentive is at risk because it is dependent on performance conditions, although on the basis of our sample, modern practice in the UK seems to eschew relative performance measures for short-term bonus. Furthermore, the short-term incentive opportunities are most often presented in terms of accounting performance. Bonus is typically paid at different levels of performance between a lower and an upper threshold. Annual bonus is either paid in cash, or with a mixture of cash and shares. In many cases, the short-term bonus paid in cash and shares is deferred. Typically no further performance conditions need to be met to claim the deferred cash or shares, though if the share price falls in the deferral period, then the executive suffers a loss. So, in the case of a deferred short-term bonus payment, an executive suffers two forms of risk: first that corporate 
performance is insufficient to earn the highest level (or any) bonus and second, that once earned, if the bonus is deferred there is the risk of loss commensurate with any fall on the company share price.

Executives are also usually eligible for grants of executive share options and /or grants of restricted shares. Obviously the value of share options and shares move in line with the share price and so, to some degree, the risk-reward opportunities of shareholders and executives are aligned. Further, in the UK, virtually all grants are subject to performance conditions before vesting and may be more accurately referred to as performance-options or performance-shares. Similar to the short-term incentive a maximum award vests for performance beyond an upper threshold while no award vests for performance below a lower threshold. The award typically vests at different levels of performance between the lower and upper threshold.

The performance conditions for long-term incentives are invariably set in relative terms against the market in general or a group of firms in the same sector. In an optimal contracting framework, this relative performance evaluation (RPE) has two beneficial features. From the executive's perspective, RPE ameliorates the problem of losing an incentive payment due to uncontrollable risks common to the market or sector, whilst at the same time ensuring that executives do not receive excessive incentive payments due to exogenous circumstances that benefit all firms (Holmström, 1982).

A measure of executive pay that is widely used in empirical studies is cash compensation (for example Liu and Stark, 2009) and is usually the sum of basic salary and annual bonus paid. Cash compensation is a measure of actual realised pay because it only includes guaranteed pay or pay that has met performance criteria. Cash compensation is the most consistently defined measure in the literature although there are still some differences across studies. Some studies include all cash compensation, including allowances (Gregg et al., 2005 and Conyon et al., 2001). Others only include basic pay and annual bonus (McKnight and Tomkins, 2004; McKnight and Tomkins, 1999; Henderson and Frederickson, 1996). A number of studies only measure cash compensation (Liu and Stark, 2009; Girma et al. 2007; Gregg et al. 2005; Johnston, 2002; Benito and Conyon, 1999). Cash compensation is a relatively simple measure and easily obtained, but the major drawback is that it does not include the long-term incentive element of executive remuneration. Excluding long-term incentive compensation, which is implicitly linked to measures of corporate performance, 
such as growth in earnings per share (EPS) or total shareholder return (TSR), must alter the validity of the compensation measure.

Studies that report on long-term incentives or total compensation versus cash compensation find contrasting results for each measure of pay. Conyon et al. (2001) report similar significant positive coefficients for both cash and total compensation. However, the finding for long-term incentives is less significant and reports a much larger positive coefficient. Core et al. (1999), also report similar results for cash and total compensation but find the results for basic pay are remarkably different. McKnight et al. (2000) find a relationship between corporate performance and both short-term and long-term pay; however, salary is predominantly determined by company size. These findings suggest there is evidence that dividing compensation into its various elements is an important prerequisite to understanding the determinants of executive compensation.

Studies that include long-term incentives adopt different approaches which might lead to inconsistency in the reported findings. For example, many studies only include stock options in the long-term incentive measure (McKnight and Tomkins, 2004; Cordeiro and Veliyath, 2003) with relatively few considering the value of performance shares (Core et al., 2008). The valuation of options and shares also varies widely, for example, Jensen and Murphy (1990) use Black-Scholes pricing methodology to value the options, McKnight and Tomkins (1999) use the minimum share option (MSO) valuation model, and Cordeiro and Veliyath (2003) use a binomial valuation model. Henderson and Frederickson (1996) value options at $25 \%$ of the exercise price, a method used more recently by Berrone and Gomez-Mejia (2009).

The treatment of performance-share grants has also varied. Research has attempted to consider the impact of performance conditions on the incentive payout by discounting performance share awards for the probability of vesting. Conyon et al. (2001) measure incentive compensation and discount LTIP awards by $20 \%$ to reflect the performance conditions. Other research uses the face value of the award at the time of grant (Eichholtz et al., 2008; Core et al., 1999), whilst Core et al. (2008) use long term incentive payouts in their measure of total realised pay. Our own measures of CEO compensation are set out in detail in section 3. 


\subsection{Company size}

There is substantial consistent evidence to suggest that company size is a significant predictor of chief executive compensation which is typically explained by the increased complexity of managing a large firm (Gregg et al., 2005; Cordeiro and Veliyath, 2003; Conyon et al., 2000). There are several convincing theoretical arguments which predict firm size to be related to executive pay. For example, proponents of managerial power theory suggest that executives exert power to seek control of the remuneration process and use their influence to link pay to factors, like firm size, which are more 'stable' and associated with less compensation risk (Chan, 2008).

The positive association between firm size and executive compensation is supported by UK company remuneration policy where it is normal practice to benchmark chief executive compensation against peers of similar size firms. Since August 2002, it is a UK statutory requirement that the company executive remuneration policy is detailed in the remuneration report and it usually states the specific policy for each element of compensation. Chief executive basic pay is consistently benchmarked against a comparator group of companies. For example, the food and beverage UK quoted company, Diageo benchmark salary "against the top 30 companies in the FTSE 100 excluding financial services businesses" (Diageo, Annual Report and Accounts, 2007, p.58). Since salary benchmarking according to firm size is typical practice among UK firms, it is therefore not surprising that the extant literature finds company size to be a significant positive determinant of basic pay. Furthermore, company size is also expected to be the major determinant of total compensation, because target short and long-term incentive awards are typically expressed as a percentage of salary (Murphy, 1999). For example, the Diageo short-term incentive target is 100 percent of salary, the performance-share option grant is a maximum 375 percent of salary and the performance-share award is a maximum 250 percent of salary. Consequently, if basic salary is a function of company size it is likely that company size will also influence other elements of compensation. Overall, then, it is hypothesised that company size will be positively associated with basic pay, short-term PRP, long-term PRP, and, therefore, total PRP. The hypotheses are set out in Figure 1. Company size is measured using firm sales and the precise measurement specification is detailed in section 3. 


\subsection{Corporate performance}

It is evident from our data collection that compensation contracts incorporate elements of absolute company performance and relative company performance. Payments of shortterm incentives are typically, though not exclusively, linked to an accounting profitability measure. For example, the Diageo remuneration report states that the short-term incentive is 'entirely based on Diageo's overall financial performance' and 'at least $70 \%$ based on profit measures' (Diageo, Annual Report and Accounts, 2007, p.58). Long-term incentives via performance-share options and performance-share plans are contingent on corporate performance through vesting conditions such as growth in earnings per share (EPS) and/or relative total shareholder return (TSR).

However, although the remuneration reports in our sample often declare that executive pay varies according to absolute and/or relative corporate performance, the empirical evidence typically offers only weak support for these declarations (Girma et al., 2007; Conyon et al., 2000). It is proposed that one reason for the small association is a reflection of the measurement of the chief executive compensation variable. The theoretical framework, Figure 1, proposes from an agency theory perspective that corporate performance is significantly and positively associated with all elements of pay (McKnight and Tomkins, 1999; Jensen and Murphy, 1990). It is also proposed from a relative performance evaluation theory perspective, that after controlling for individual firm performance, peer group performance is significantly and negatively associated with all elements of pay (Benito and Conyon, 1999; Gibbons and Murphy, 1990).

Specifically, we hypothesize that short-term company performance measured for the most part, though not only, in absolute terms to be strongly related to short-term performance-realised pay. And because strong absolute performance is likely to be strong in relative terms, it is further expected that peer group performance is negatively related to short-term performance-realised pay. Turning to realised long-term incentive payments, we hypothesize that these will be strongly related to relative performance measures, but also to absolute corporate performance, on the basis that good relative performance is likely to be reflected in good absolute performance.

While it is evident from company remuneration reports that compensation contracts incorporate elements of absolute company performance and relative company performance, there is also an element of the compensation that is not necessarily 
dependent on performance, namely basic pay. For example, UK remuneration reports contain statements similar to the following illustrations: 'Base salaries are not performancerelated', Enodis (Annual Report and Accounts, 2005, p.39) and 'The payment of base salaries is not related to company performance', Northumbrian Water Group (Annual Report and Accounts, 2005, p.48). Therefore, as is the reason for dividing pay in this way, it is expected that the strength of the pay-performance association will depend on the specific hypothesis being tested. The hypotheses are set out in Figure 1. Corporate performance is measured using earnings per share and shareholder return. The precise measurement specification for absolute firm performance and peer group performance is detailed in section 3.

[Insert Figure 1 about here]

\section{Data and estimation methods}

\subsection{Data sources and sample selection}

The chief executive compensation data used for this study is hand collected from company annual reports and accounts in order to facilitate the precision and detail necessary to construct the compensation variables. Other readily available data sources, such as Datastream, Manifest or the Hemmington Scott corporate information database, do not provide the necessary detail required to construct the measures of compensation for this study. The company financial information is obtained from Datastream. The companies were selected from the FTSE-350 list on $31^{\text {st }}$ December 2007 (excluding financial services, real estate and investment trusts). Executives with fewer than two consecutive years are excluded. Executives combining the role of Chairman and CEO are also excluded because the additional responsibilities might influence the compensation arrangements. The final dataset comprises an unbalanced panel with a maximum of 204 companies and 905 executive-years from 2003 to 2007.

\subsection{Dependent compensation variables}

The dependent chief executive compensation variables used in this study are categorized as basic pay or performance-realised pay (PRP). PRP is defined as pay that has satisfied predetermined performance conditions. A performance-option or performance-share grant is performance-contingent pay because it only vests if performance conditions are satisfied: 
the award only becomes 'realised' upon vesting and not at grant. Therefore, the valuation of performance related long-term incentive grants only reflects the potential reward and does not reflect the actual payout from the incentive. However, we recognise that if performance conditions are not specified, (more typical of US practice), the incentive is earned at grant (time and continued employment being the only vesting restrictions).

Basic pay (BP) is measured as the annual salary reported in the directors' remuneration report. Short-term performance-realised pay (S.PRP) is measured as paid cash bonus plus shares, plus any guaranteed deferred cash and/or share compensation with no further performance conditions attached. Long-term performance-realised pay (L.PRP) is measured as the value of performance-options vesting in the current year, plus the value of performance-shares vesting in the current year, plus the value of long-term performancecash awards vesting in the current year, plus the grant value of time-vesting options, plus the grant value of time-vesting shares. Total performance-realised pay (T.PRP) is measured as BP, plus any other fixed cash paid in the current year, plus S.PRP, plus L.PRP.

Following Berrone and Gomez-Mejia (2009), all calculations involving either performance-options or time-vesting options are valued at $25 \%$ of their exercise value. Previous studies find quantitatively similar results for this method compared to more sophisticated techniques such as the Black-Scholes valuation model (see McKnight and Tomkins, (1999) for a discussion of executive stock option valuation techniques and their merits). All calculations involving performance-shares or time-vesting shares are valued as at the fiscal year-end company share price. The compensation variables are transformed into the natural logarithm in order to impose a constant percentage effect of the independent variable on the dependent variable (Wooldridge, 2003).

\subsection{Independent company performance and size variables}

The company performance variables are selected to replicate measures typically found in the chief executive compensation contracts and also reflect the way the data has been collected. For example, basic pay is typically set at the start of a new financial year. S.PRP is paid in the following year to which it is earned, but it is reported in the accounts in the year in which it is earned. Therefore it is expected that the relationship between firm performance and S.PRP is contemporaneous. In contrast L.PRP is typically reported in the year it is paid and based on the previous three years corporate performance. 
We measure short-term performance as earnings per share (S.EPS) and shareholder return (S.RET). S.RET is the annual change in the natural logarithm of the return index. We measure long-term performance as the three year change in the natural logarithm of the return index (L.RET). Company size is measured as the natural logarithm of total company sales.

Industry stock market returns are calculated from a portfolio of firms in the same FTSE350 sector index. Company return index data is available from Datastream on a daily basis which enables precise industry stock market returns to be calculated to match each firm's own fiscal year-end. FTSE-350 index stock market returns (excluding financial services, real estate and investment trusts) are calculated in the same way. As with the company performance data we match the industry and market return measures with criteria typically found in company incentive plans. We therefore use the median stock market return rather than the mean return (Benito and Conyon, 1999) or mean value-weighted return (Liu and Stark, 2009; Aggarwal and Samwick, 1999) used in previous studies. Short-term industry performance is measured as the median annual return of the FTSE-350 share sector index (S.IN.RET). Short-term market performance is measured as the median annual return of the FTSE-350 share index (S.MK.RET). Long-term industry performance is measured as the median three year return of the FTSE-350 share sector index (L.IN.RET). Long-term market performance is measured as the median three year return of the FTSE-350 share index (L.MK.RET).

\subsection{Estimation method}

This section sets out the econometric models employed to estimate the association between firm performance and chief executive pay; peer group performance and chief executive pay; and, firm size and chief executive pay. The general model used in this study is specified below.

$$
(\ln P A Y)=\beta_{0}+\beta_{1}(\text { FIRM })+\beta_{2}(\text { PEER })+\beta_{3}(\text { SIZE })+\mu
$$

Variations on the general model are related to the dependent variable in question and to the performance measures including any lag structures relevant to each model. The dependent $\ln P A Y$ variable is a measure of chief executive compensation and assumes a 
different specification for each model/group of hypotheses being tested. FIRM is own firm performance and PEER is the related benchmark performance of the group to which the firm belongs. The FIRM and PEER group performance variables also adopt different specifications for each model/group of hypotheses being tested.

The strength of the relationship between absolute firm performance and chief executive pay is represented by the coefficient $\beta_{l}$. The dependent compensation variable is in logarithmic form and therefore, $\beta_{1}$ the coefficient of FIRM, is known as the pay-forperformance elasticity. The elasticity of $\ln P A Y$ with respect to FIRM is determined by the size of $\beta_{1}$. According to Holmstrom and Milgrom (1987), evidence of RPE is based on the strength and the sign of the coefficient of $\beta_{2}$. Whilst controlling for absolute firm performance, $\beta_{2}$ the coefficient of PEER, is expected to be significant and negative (Benito and Conyon, 1999; Gibbons and Murphy, 1990). The strong form of the hypothesis expects the coefficient $\beta_{2}$ of the PEER explanatory variable to be significant negative and equal in size to the predicted positive coefficient of $\beta_{1}$ of the FIRM explanatory variable. The predicted result is consistent with the complete filtering out of the market risk component of firm performance. The weak form of the hypothesis simply predicts that $\beta_{2}$ is significant negative but smaller in size than $\beta_{1}$. This is consistent with only partial filtering out of market performance (Rajgopal, 2006).

An important assumption of Holmstrom's (1982) RPE hypothesis is that peer group performance is positively associated with firm performance (Liu and Stark, 2009; Walker, 1989). It is therefore necessary to test the association between peer group performance and absolute firm performance before estimating each of the models. The different models used to test the sets of hypotheses 1 through 4 are described next. We employ fixed effects estimation with robust standard errors, clustered by year and company CEO, to estimate the following models.

\subsubsection{Model 1, testing hypotheses $1 a, 1 b$ and $1 c$}

To begin, we regress the independent variables on the natural logarithm of basic pay (BP).

$$
(B P)_{i t}=\gamma_{i}+\alpha_{t}+\beta_{1}(\text { S.FIRM })_{i t-1}+\beta_{2}(\text { S.PEER })_{i t-1}+\beta_{3}(\text { SIZE })_{i t-1}+\mu_{i t}
$$


The subscript $i$ refer to a CEO-firm pair and the subscript $t$ refer to time in years. $\alpha_{t}$ is a time trend. $\gamma_{i}$ is a time-invariant chief executive/firm specific effect and differs between firms. $\mu_{i t}$ is the idiosyncratic error. S.FIRM is a vector of short-term firm performance variables (S.EPS and S.RET). S.PEER is a vector of short-term peer group performance variables (S.IN.RET and S.MK.RET). SIZE is firm sales. BP is determined at the start or set part-way through the financial year. $B P$ is therefore assumed to be associated with the previous year's financial performance. For this reason the performance variables and company size variable are lagged one year.

\subsubsection{Model 2, testing hypotheses $2 a, 2 b$ and $2 c$}

To test short term incentive effects, we regress the independent variables on the natural logarithm of short-term performance-realised pay (S.PRP).

$$
(S . P R P)_{i t}=\gamma_{i}+\alpha_{t}+\beta_{1}(\text { S.FIRM })_{i t}+\beta_{2}(\text { S.PEER })_{i t}+\beta_{3}(\text { SIZE })_{i t-1}+\mu_{i t}
$$

The subscript $i$ refer to a CEO-firm pair and the subscript $t$ refer to time in years. $\alpha_{t}$ is a time trend. $\gamma_{i}$ is a time-invariant chief executive/firm specific effect and differs between firms. $\mu_{i t}$ is the idiosyncratic error. S.FIRM is a vector of short-term firm performance variables (S.EPS and S.RET). S.PEER is a vector of short-term peer group performance variables (S.IN.RET and S.MK.RET). SIZE is firm sales. S.PRP is determined at the end of the financial year and is paid in the following year to which it is earned. However, it is generally reported in the annual report and accounts in the year to which it relates and has been collected in this way for the purpose of this investigation. Therefore, it is expected that the relationship between corporate performance and S.PRP is contemporaneous. Hence the firm and peer group performance variables are not lagged.

\subsubsection{Model 3, testing hypotheses $3 a, 3 b$ and $3 c$}

To test long term incentive effects, we regress the independent variables on the natural logarithm of long-term performance-realised pay (L.PRP).

$$
\left(L_{P} \cdot P R P\right)_{i t}=\gamma_{i}+\alpha_{t}+\beta_{1}(L . F I R M)_{i t-1}+\beta_{2}(L . P E E R)_{i t-l}+\beta_{3}(\text { SIZE })_{i t-1}+\mu_{i t}
$$


The subscript $i$ refer to a CEO-firm pair and the subscript $t$ refer to time in years. $\alpha_{t}$ is a time trend. $\gamma_{i}$ is a time invariant chief executive/firm specific effect and differs between firms. $\mu_{i t}$ is the idiosyncratic error. L.FIRM is long-term firm performance (L.RET). L.PEER is a vector of long-term peer group performance variables (L.IN.RET and L.MK.RET). SIZE is firm sales. L.PRP is determined at the end of a pre-determined performance period which may or may not be the fiscal year-end. L.PRP is typically reported in the year which it is paid and based on the previous three years corporate performance. For this reason the performance variables are lagged one year.

\subsubsection{Model 4, testing hypotheses $4 a, 4 b, 4 c, 4 d$ and $4 e$}

In order to understand the factors that are proposed to impact on the natural logarithm of total performance-realised pay (T.PRP) we estimate the following two models:

$$
\begin{aligned}
& (\text { T.PRP })_{i t}=\gamma_{i}+\alpha_{t}+\beta_{1}(\text { S.FIRM })_{i t}+\beta_{2}(\text { S.PEER })_{i t}+\beta_{3}(\text { SIZE })_{i t-l}+\mu_{i t} \\
& (\text { T.PRP })_{i t}=\gamma_{i}+\alpha_{t}+\beta_{I}(\text { L.FIRM })_{i-1}+\beta_{2}(\text { L.PEER })_{i t-1}+\beta_{3}(\text { SIZE })_{i t-1}+\mu_{i t}
\end{aligned}
$$

The subscript $i$ refer to a CEO-firm pair and the subscript $t$ refer to time in years. $\alpha_{t}$ is a time trend. $\gamma_{i}$ is a time-invariant chief executive/firm specific effect and differs between firms. $\mu_{i t}$ is the idiosyncratic error. In model (4S), S.FIRM is a vector of short-term firm performance variables (S.EPS and S.RET). S.PEER is a vector of short-term peer group performance variables (S.IN.RET and S.MK.RET). In model (4L), L.FIRM is long-term firm performance (L.RET). L.PEER is a vector of long-term peer group performance variables (L.IN.RET and L.MK.RET). In model (4S) and (4L), SIZE is firm sales.

T.PRP is assumed to be associated with the current financial year's performance since it includes S.PRP. Therefore in model $(4 S)$ it is expected that the relationship between shortterm corporate performance and T.PRP is contemporaneous. Hence the firm and peer group performance variables are not lagged in model $(4 S)$. In model $(4 L)$ T.PRP is assumed to be associated with the previous three years corporate performance and therefore the longterm performance variables are lagged one year. 
[Insert Table 1 and 2 about here]

\section{Empirical results}

In this section we present summary statistics and the results of fixed effects regressions. The descriptive statistics and Pearson's correlation matrix are reported in Tables 1 and 2 respectively. The main empirical results testing for the relationship between corporate performance and CEO compensation are reported in Tables 3 to 7.

\subsection{Descriptive statistics and correlations}

The descriptive data for the chief executive compensation variables and selected independent variables are shown in Table 1. The mean CEO basic pay data has increased from $£ 450,000$ in 2003 to $£ 567,000$ in 2007 for our unbalanced sample of firms. The mean CEO total PRP has very nearly doubled from $£ 1,094,000$ in 2003 to $£ 2,071,000$ in 2007. Median short-term PRP increases progressively as a percentage of median basic pay from $50 \%$ in 2003 to $91 \%$ in 2007. Whereas, median long-term PRP is only $32 \%$ of basic pay in 2005 versus a high of $75 \%$ in 2007.

The correlation matrix reports the Pearson's correlation coefficients for the independent variables. As expected absolute firm shareholder return is significantly correlated with median industry and median market return for the corresponding time lags (coefficients ranging from 0.52 to 0.67 ). This high level of correlation indicates that evidence of RPE in the compensation measures should be confirmed by negative market and industry coefficients (Liu and Stark, 2009). Market return and industry return are also significant and highly correlated (coefficients above 0.71 ). The pooled OLS regression of peer group performance on firm performance is highly significant for all models.

\subsection{Regression results}

\subsubsection{Basic pay (BP)}

In Table 3, we present fixed effects regressions of basic pay on measures of firm performance, market and sector performance and company size. There is some evidence, with respect to shareholder returns, to support the alternate hypothesis 1 a that firm performance is associated with basic pay. Models 1.4, 1.5 and 1.6 reports a significant positive association between shareholder return and basic pay, although the effect is only 
small. Our EPS measure is not significant in determining basic pay. FTSE-350 sector and market performance are significant and negatively associated with basic pay demonstrating some evidence of RPE. The null hypothesis $1 \mathrm{~b}$ can be rejected. In terms of hypothesis $1 \mathrm{c}$, company size, measured as company sales, is significant and positively associated with basic pay. The coefficient of the company sales variable is around 0.10 for all models indicating that a $10 \%$ change in sales is associated with a $1 \%$ change in basic pay.

Overall our results for basic pay are comparable to those reported by McKnight and Tomkins (1999). McKnight and Tomkins also find company size and shareholder returns to explain CEO basic pay and like us find EPS to be not significant.

[Insert Table 3 about here]

\subsubsection{Short-term performance-realised pay (S.PRP)}

Table 4 reports the fixed effects regressions of short-term PRP on measures of firm performance, market and sector performance and company size. In terms of absolute firm performance, EPS is not significant, whereas annual shareholder returns are significant and positively related to short-term PRP. This is consistent with the alternate hypothesis $2 \mathrm{a}$. Of particular note is the size of the coefficients on shareholder returns which range from a statistically significant 1.33 to a statistically significant 2.10 . This result infers that a CEO will receive an increase of between $13 \%$ and $21 \%$ in short-term PRP for a $10 \%$ increase in annual shareholder returns. The impact of firm performance on short-term PRP is much more pronounced than has been reported elsewhere in the literature. For example a recent study on annual bonus payments by Bruce et al. (2007) reported only a $2.19 \%$ change in bonus for a $10 \%$ increase in shareholder returns.

[Insert Table 4 about here]

The hypothesis $2 \mathrm{~b}$ proposes a negative association between short-term FTSE-350 market and sector performance with short-term PRP. Sector peer group performance reports a negative association with short-term PRP but is not significant. However, our measure of market performance, median annual FTSE-350 stock market returns, is significant and negatively associated with short-term PRP, providing strong evidence of RPE. 
In each model the company sales variable is negative but not significant. We can therefore reject the alternate hypothesis $2 c$ that short-term PRP varies positively according to company size.

In summary the results reported in Table 4 show that absolute short-term shareholder returns are strongly related to short-term PRP and market peer group returns are negatively related to short-term PRP, which is consistent with the RPE hypothesis. Company sales are not significant. This is an important reversal of previous studies, which typically find company size to be the most consistent and significant positive determinant of chief executive pay, with only a weak relationship between corporate performance and pay.

\subsubsection{Long-term performance-realised pay (L.PRP)}

Table 5 reports the fixed effects regressions of long-term PRP on measures of firm performance, market and sector performance and company size. Long-term shareholder returns are significant and positively associated with long-term PRP for all models which is in keeping with our prediction from hypothesis 3a. The coefficients are large and range from 1.73 to 2.37 . This result indicates that a CEO will receive an increase of between $17 \%$ and $24 \%$ in long-term PRP for a $10 \%$ increase in three year shareholder returns. This result provides clear evidence of a strong relationship between long-term corporate performance and long-term PRP. The only UK study to report similar findings is McKnight and Tomkins (1999). They use the minimum share option valuation model and report a large, significant and positive association between the changes in the value of executive share options and shareholder return. Other studies using measures of total compensation (Liu and Stark, 2009; Albuquerque, 2009) find coefficients of a much smaller magnitude.

[Insert Table 5 about here]

The hypothesis $3 \mathrm{~b}$ proposes a negative association between long-term FTSE-350 market and sector performance with long-term PRP. Market peer group performance reports a negative association with long-term PRP but is not significant. However, our measure of FTSE-350 sector performance is significant and negatively associated with long-term PRP. This is strong support for the relationship between long-term incentives and relative corporate performance and consistent with RPE theory. 
In each model the company sales variable is positive but not significant. We can therefore reject the alternate hypothesis $3 c$ that long-term PRP varies positively with company size.

Overall the results reported in Table 5 show that absolute shareholder returns and relative industry performance are strongly related to long-term PRP. This is consistent with a principal-agent model of incentives designed to align the interests of executives and their shareholders.

\subsubsection{Total performance-realised pay (T.PRP)}

Table 6 and 7 reports the fixed effects regression of total PRP on measures of company performance, market and sector performance and company size. Table 6 reports the association between short-term corporate performance and total PRP. Table 7 reports the association between long-term corporate performance and total PRP.

There is insubstantial evidence that short-term performance, either EPS or shareholder returns, is associated with total PRP. We can therefore reject the alternate hypothesis $4 a$ that total PRP varies positively with short-term firm performance. However, long-term shareholder returns are significant and positively associated with total PRP. This is consistent with the alternate hypothesis $4 \mathrm{~b}$. The coefficients on shareholder returns are around 0.12 . This result indicates that a CEO will receive an increase of $1.2 \%$ in total PRP for a $10 \%$ increase in three year shareholder returns. There is also evidence to suggest total PRP varies according to peer group performance. Model 4.5(S) shows a negative association between annual FTSE-350 stock market return and total PRP providing evidence of RPE in CEO total compensation.

The hypothesis $4 \mathrm{e}$ predicts a positive association between company size and total PRP. In each model the company sales variable is significant and positive. We can therefore reject the null hypothesis and accept 4e, total PRP varies positively according to company size.

Overall the results for total PRP are very similar to the extant literature but remarkably different to our own results presented in Tables 4 and 5 for short-term PRP and long-term PRP. This would appear to imply that it is imperative to divide CEO compensation in terms of its individual components in order to comprehend the association between corporate performance and CEO pay. 
[Insert Table 6 and 7 about here]

\section{Concluding remarks}

This study has important theoretical and practical implications. Theoretically, the study contributes to the extant literature by defining executive compensation in terms of performance-realised pay. As we have argued, there is a much greater likelihood of registering a strong relationship between pay and performance using realised compensation measures, than there would be with measures of contingent incentive pay. Our empirical results support the theoretical divide of compensation in this way.

We show that using performance-realised measures of compensation is a necessary condition for investigating the underlying relationship between corporate performance and chief executive pay. Above all else this study provides new and convincing evidence that performance-realised pay is associated with peer group performance. Company shareholder returns are positively related to short-term performance-realised pay and FTSE-350 market returns are negatively associated with short-term realised. Long-term shareholder returns are positively associated with long-term performance-realised pay and FTSE-350 sector return is negatively associated with long-term realised.

Various groups including institutional investors, the government and the media require that chief executive pay is determined by corporate performance. This study shows a positive relationship between corporate performance and measures of realised pay. To some degree this study may alleviate the concerns held by some stakeholder groups that pay is not clearly linked to corporate performance. These findings will be of particular practical importance to investors who expect the interests of executives to be aligned with those of the company shareholders, via an incentive contract that rewards executives for enhanced corporate performance and consequently shareholder wealth maximisation. Our results also confirm that changes to improve corporate governance practice in the field of executive pay are working to the benefit of shareholders. 


\section{References}

Aggarwal, R. K., Samwick, A. A., 1999. Executive compensation, strategic competition, and relative performance evaluation: Theory and evidence. Journal of Finance 54, 1999-2043.

Albuquerque, A., 2009. Peer firms in relative performance evaluation. Journal of Accounting and Economics 48, 69-89.

Benito, A., Conyon, M. J., 1999. The governance of directors' pay: evidence from UK companies. Journal of Management and Governance 3, 117-136.

Berrone, P., Gomez-Mejia, L. R., 2009. Environmental performance and executive compensation: an integrated agency-institutional perspective. Academy of Management Journal 52, 103-126.

Bruce, A., Buck, T., Main, B. G. M., 2005. Top executive remuneration: A view from Europe. Journal of Management Studies 42, 1493-1506.

Buck, T., Bruce, A., Main, B. G. M., Udueni, H., 2003. Long term incentive plans, executive pay and UK company performance. Journal of Management Studies 40, 1709-1727.

Cadbury, Sir A., 1992. Committee on the financial aspects of corporate governance. London, Gee.

Câmara, A., 2001. The pricing of relative performance based incentives for executive compensation. Journal of Business Finance \& Accounting 28, 1149-1188.

Chan, M., 2008. Executive compensation. Business and Society Review 113, 129-161.

Combined Code, 1998, 2003, 2006, 2008, 2010. The combined code on Corporate Governance. London, Financial Reporting Council.

Conyon, M. J., 1997. Corporate governance and executive compensation. International Journal of Industrial Organization 15, 493-509.

Conyon, M. J., 1998. Directors' pay and turnover: an application to a sample of large UK firms. Oxford Bulletin of Economics and Statistics 60, 485-507. 
Conyon, M. J., Leech, D., 1994. Top pay, company performance and corporate governance. Oxford Bulletin of Economics and Statistics 56, 229-247.

Conyon, M. J., Peck, S. I., Sadler, G. V., 2000. Econometric modelling of UK executive compensation. Managerial Finance 26, 3-20.

Conyon, M. J., Peck, S. I., Sadler, G. V., 2001. Corporate tournaments and executive compensation: evidence from the UK. Strategic Management Journal 22, 805-815.

Cordeiro, J. J., Veliyath, R., 2003. Beyond pay for performance: a panel study of the determinants of CEO compensation. American Business Review 21, 56-66.

Core, J. E., Guay, W., Larcker, D. F., 2008. The power of the pen and executive compensation. Journal of Financial Economics 88, 1-25.

Core, J. E., Holthausen, R. W., Larcker, D. F., 1999. Corporate governance, chief executive officer compensation, and firm performance. Journal of Financial Economics 51, 371-406.

Cosh, A., Hughes, A., 1997. Executive remuneration, executive dismissal and institutional shareholdings. International Journal of Industrial Organization 15, 469-492.

Devers, C. E., Cannella, A. A., Reilly, G. P., Yoder, M. E., 2007. Executive Compensation: A Multidisciplinary Review of Recent Developments. Journal of Management 33, 1016-1077.

Diageo, 2007. Annual Report and Accounts. London, Diageo.

Directors' Remuneration Report Regulations, 2002. Available from: http://www.opsi.gov.uk [Accessed $18^{\text {th }}$ September 2007].

Eichholtz, P. M. A., Kok, N., Otten, R., 2008. Executive compensation in UK property companies. Journal of Real Estate Finance and Economics 36, 405-426.

Enodis, 2005. Annual Report and Accounts. 
Filatotchev, I., Jackson, G., Gospel, H., Allcock, D., 2007. Key drivers of 'good' corporate governance and the appropriateness of UK policy responses. The Department of Trade and Industry and King's College London.

Gibbons, R., Murphy, K. J., 1990. Relative performance evaluation for chief executive officers. Industrial and Labor Relations Review 43, 30-51.

Girma, S., Thompson, S., Wright, P. W., 2007. Corporate governance reforms and executive compensation determination: evidence from the UK. The Manchester School 75, 65-81.

Greenbury, Sir R., 1995. Directors' remuneration: report of a study group Chaired by Sir Richard Greenbury. London, Gee.

Gregg, P., Jewell, S., Tonks, I., 2005. Executive pay and performance in the UK 1994-2002. CMPO Working Paper Series No. 05/122.

Gregory-Smith, I., 2009. Chief executive pay and non-executive director pay in the UK: optimal contracting vs. Rent extraction. NUBS Research Paper Series No. 2009-02.

Hampel, R., 1998. Committee on corporate governance. London, Gee.

Hay Group, 2006. U.S. will move toward European long-term incentive model in 3-5 years. Available from: http://www.haygroup.com [Accessed $3^{\text {rd }}$ June 2008].

Henderson, A. D., Fredrickson, J. W., 1996. Information processing demands as a determinant of CEO compensation. Academy of Management Journal 39, 575-606.

Higgs, D., 2003. Review of the role and effectiveness of non-executive directors. UK, The Stationary Office.

Holmström, B., 1982. Moral hazard in teams. Bell Journal of Economics 13, 324-340.

Holmström, B., Milgrom, P., 1987. Aggregation and linearity in the provision of intertemporal incentives. Econometrica 55, 303-328. 
Jensen, M. C., Murphy, K. J., 1990. Performance pay and top-management incentives', Journal of Political Economy 98, 225-264.

Johnston, J., 2002. Tenure, promotion and executive remuneration. Applied Economics 34, 993-997.

Kuang, Y. F., Qin, B., 2009. Performance-vested stock options and interest alignment. The British Accounting Review 41, 46-61.

Liu, L. S., Stark, A. W., 2009. Relative performance evaluation in board cash compensation: UK empirical evidence. The British Accounting Review 41, 21-30.

Main, B. G. M., Bruce, A., Buck, T., 1996. Total board remuneration and company performance. The Economic Journal 106, 1627-1644.

McKnight, P. J., Tomkins, C., 1999. Top executive pay in the United Kingdom: a corporate governance dilemma. International Journal of the Economics of Business 6, 223-243.

McKnight, P. J., Tomkins, C., 2004. The implications of firm and individual characteristics on CEO pay. European Management Journal 22, 27-40.

McKnight, P. J., Tomkins, C., Weir, C., Hobson, D., 2000. CEO age and top executive pay: a UK empirical study. Journal of Management and Governance 4, 173-187.

Murphy, K. J., 1999. Executive compensation' in Ashenfelter, O. and Card, D. (eds), Handbook of Labor Economics 3, 2485-2563. Amsterdam: North Holland.

Northumbrian Water Group, 2005. Annual Report and Accounts.

Rajgopal, S., Shevlin, T., Zamora, V., 2006. CEOs' outside employment opportunities and the lack of relative performance evaluation in compensation contracts. The Journal of Finance $61,1813-1844$.

Towers Perrin, 2008. Proxy season puts executive pay under the microscope. Monitor, May 2008. Available from: http://www.towersperrin.com [Accessed $3^{\text {rd }}$ June 2008]. 
Walker, M., 1989. Agency theory: a falsificationist perspective. Accounting Organizations and Society $14,433-453$.

Wooldridge, J. M., 2003. Introductory econometrics a modern approach. 2nd edition. USA, South-Western. 
Figure 1

Theoretical framework and hypotheses

\begin{tabular}{l|c|c}
\hline Factors & Prediction & Pay Element \\
\hline H1a. Short-term firm performance (S.EPS, & $(+)$ & \\
S.RET) & \multirow{2}{*}{ Basic pay (BP) } \\
\cline { 1 - 2 } H1b. Short-term peer group performance & $(-)$ & \\
(S.IN.RET, S.MK.RET) & $(+)$ & \\
\hline H1c. Company size (SALES) & & \\
\hline
\end{tabular}

\begin{tabular}{l|c|c}
\hline H2a. Short-term firm performance (S.EPS, & $(+)$ & \\
S.RET) & \multirow{2}{*}{ Short-term performance-realised pay (S.PRP) } \\
\hline H2b. Short-term peer group performance & $(-)$ & \\
(S.IN.RET, S.MK.RET) & $(+)$ & \\
\hline H2c. Company size (SALES) & $(+)$ & \\
\hline
\end{tabular}

\begin{tabular}{|c|c|c|}
\hline H3a. Long-term firm performance (L.RET) & $(+)$ & \multirow{3}{*}{ Long-term performance-realised pay (L.PRP) } \\
\hline $\begin{array}{l}\text { H3b. Long-term peer group performance } \\
\text { (L.IN.RET, L.MK.RET) }\end{array}$ & $(-)$ & \\
\hline H3c. Company size (SALES) & $(+)$ & \\
\hline
\end{tabular}

\begin{tabular}{|c|c|c|}
\hline $\begin{array}{l}\text { H4a. Short-term firm performance (S.EPS, } \\
\text { S.RET) }\end{array}$ & $(+)$ & \\
\hline $\begin{array}{l}\text { H4b. Short-term peer group performance } \\
\text { (S.IN.RET, S.MK.RET) }\end{array}$ & $(-)$ & \\
\hline H4c. Long-term firm performance (L.RET) & $(+)$ & Total performance-realised pay (T.PRP) \\
\hline $\begin{array}{l}\text { H4d. Long-term peer group performance } \\
\text { (L.IN.RET, L.MK.RET) }\end{array}$ & $(-)$ & \\
\hline H4e. Company size (SALES) & $(+)$ & \\
\hline \multicolumn{3}{|c|}{$\begin{array}{l}\text { This figure summarises the hypotheses tested in this study. S.EPS is earnings per share. S.RET is the annual change in the natural } \\
\text { logarithm of the return index. L.RET is the three year change in the natural logarithm of the return index. S.IN.RET is the median annual } \\
\text { return of the FTSE- } 350 \text { share sector index. L.IN.RET is the median three year return of the FTSE- } 350 \text { share sector index. S.MK.RET is the } \\
\text { median annual return of the FTSE- } 350 \text { share index. L.MK.RET is the median three year return of the FTSE-350 share index. SALES are total } \\
\text { company sales. BP is annual basic pay. S.PRP is the cash value of paid annual bonus (including guaranteed deferred bonus compensation } \\
\text { [paid in cash, options or shares] without additional performance conditions). L.PRP is the cash value of performance-options vesting in the } \\
\text { current year, plus performance-shares vesting in the current year, plus long-term cash plan vesting in the current year, plus the grant value } \\
\text { of time-vesting options, plus the grant value of time-vesting shares. T.PRP is the sum of basic pay, plus other cash, plus S.PRP, plus L.PRP. }\end{array}$} \\
\hline
\end{tabular}


Table 1

Descriptive statistics

\begin{tabular}{|c|c|c|c|c|c|}
\hline Variables & $\begin{array}{l}2003 \text { mean } \\
\text { (median) }\end{array}$ & $\begin{array}{l}2004 \text { mean } \\
\text { (median) }\end{array}$ & $\begin{array}{l}2005 \text { mean } \\
\text { (median) }\end{array}$ & $\begin{array}{l}2006 \text { mean } \\
\text { (median) }\end{array}$ & $\begin{array}{l}2007 \text { mean } \\
\text { (median) }\end{array}$ \\
\hline \multirow[t]{2}{*}{$\mathrm{BP}^{\mathrm{a}}$} & 450 & 474 & 508 & 536 & 567 \\
\hline & (398) & (411) & (450) & $(482)$ & (514) \\
\hline \multirow[t]{2}{*}{ S.PRP ${ }^{a}$} & 339 & 397 & 456 & 531 & 648 \\
\hline & $(200)$ & $(250)$ & $(300)$ & $(400)$ & $(470)$ \\
\hline \multirow[t]{2}{*}{ L.PRP ${ }^{a}$} & 420 & 662 & 518 & 704 & 1,073 \\
\hline & (170) & (178) & $(142)$ & $(270)$ & $(386)$ \\
\hline \multirow[t]{2}{*}{ T.PRP ${ }^{a}$} & 1,094 & 1,386 & 1,414 & 1,615 & 2,071 \\
\hline & (753) & (933) & (957) & $(1,104)$ & $(1,352)$ \\
\hline \multirow[t]{2}{*}{ S.EPS } & 0.192 & 0.252 & 0.339 & 0.406 & 0.468 \\
\hline & $(0.156)$ & $(0.166)$ & $(0.217)$ & $(0.244)$ & $(0.321)$ \\
\hline \multirow[t]{2}{*}{ S.RET } & 0.079 & 0.261 & 0.265 & 0.256 & 0.110 \\
\hline & $(0.152)$ & 0.236 & $(0.240)$ & $(0.233)$ & $(0.148)$ \\
\hline \multirow[t]{2}{*}{ L.RET } & 0.006 & 0.184 & 0.590 & 0.782 & 0.653 \\
\hline & $(0.183)$ & $(0.263)$ & (0.591) & $(0.746)$ & $(0.653)$ \\
\hline \multirow[t]{2}{*}{ SALES $^{a}$} & $3,552,160$ & $3,755,285$ & $4,625,148$ & $4,700,791$ & $4,413,940$ \\
\hline & $(1,095,100)$ & $(1,117,136)$ & $(1,150,032)$ & $(1,088,100)$ & $(1,241,200)$ \\
\hline
\end{tabular}

This table reports descriptive statistics for dependent and selected independent variables for the sample of 204 FTSE-350 companies over the period of 2003-2007. BP is annual basic pay. S.PRP is the cash value of paid annual bonus (including guaranteed deferred bonus compensation [paid in cash, options or shares] without additional performance conditions). L.PRP is the cash value of performanceoptions vesting in the current year, plus performance-shares vesting in the current year, plus long-term cash plan vesting in the current year, plus the grant value of time-vesting options, plus the grant value of time-vesting shares. T.PRP is the sum of basic pay, plus other cash, plus S.PRP, plus L.PRP. S.EPS is earnings per share. S.RET is the annual change in the natural logarithm of the return index. L.RET is the three year change in the natural logarithm of the return index. SALES are total company sales. ${ }^{a}(£ 000)$. 
Table 2

Pearson correlation matrix: independent variables

\begin{tabular}{|c|c|c|c|c|c|c|c|c|c|c|c|c|}
\hline $\begin{array}{l}\text { Independent } \\
\text { Variable }\end{array}$ & 1 & 2 & 3 & 4 & 5 & 6 & 7 & 8 & 9 & 10 & 11 & 12 \\
\hline 1. S.EPS & 1 & & & & & & & & & & & \\
\hline 2. S.EPS $\mathrm{t}_{\mathrm{t}-1}$ & $0.75^{* *}$ & 1 & & & & & & & & & & \\
\hline 3. S.RET & $0.13^{* *}$ & -0.02 & 1 & & & & & & & & & \\
\hline 4. S.RET $\mathrm{t}_{\mathrm{t}-1}$ & $0.16^{* *}$ & $0.23 * *$ & $-0.14^{* *}$ & 1.00 & & & & & & & & \\
\hline 5. L.RET $\mathrm{t}_{\mathrm{t}-1}$ & $0.29 * *$ & $0.38 * *$ & -0.03 & $0.50 * *$ & 1.00 & & & & & & & \\
\hline 6. S.MK.RET & 0.01 & -0.03 & $0.54 * *$ & $-0.18^{* *}$ & $-0.14 * *$ & 1.00 & & & & & & \\
\hline 7. S.MK.RET ${ }_{\mathrm{t}-1}$ & 0.09 & $0.12^{*}$ & $-0.13 * *$ & $0.58 * *$ & $0.27 * *$ & $-0.29 * *$ & 1.00 & & & & & \\
\hline 8. L.MK.RET & $0.17 * *$ & $0.18 * *$ & $-0.13^{* *}$ & $0.30 * *$ & $0.52 * *$ & $-0.25^{* *}$ & $0.48^{* *}$ & 1.00 & & & & \\
\hline 9. S.IN.RET & $0.12 * *$ & 0.02 & $0.62 * *$ & $-0.12 * *$ & -0.05 & $0.78^{* *}$ & $-0.20 * *$ & $-0.21 * *$ & 1.00 & & & \\
\hline 10. S.IN.RET & $0.17^{* *}$ & $0.21 * *$ & -0.09 & $0.63 * *$ & $0.36 * *$ & $-0.21 * *$ & $0.81 * *$ & $0.44 * *$ & $-0.14^{* *}$ & 1.00 & & \\
\hline 11. L.IN.RET & $0.25^{* *}$ & $0.29 * *$ & -0.03 & $0.34 * *$ & $0.67 * *$ & $-0.18^{* *}$ & $0.38 * *$ & $0.71 * *$ & -0.06 & $0.54 * *$ & 1.00 & \\
\hline 12. $\mathrm{SALES}_{\mathrm{t}-1}$ & $0.20 * *$ & $0.20 * *$ & $-0.17^{* *}$ & $-0.12^{* *}$ & $-0.14^{* *}$ & -0.01 & 0.02 & 0.04 & -0.05 & 0.01 & 0.01 & 1.00 \\
\hline
\end{tabular}

This table reports Pearson's correlation coefficients for the independent variables. S.EPS is earnings per share. S.RET is the annual change in the natural logarithm of the return index. L.RET is the three year change in the natural logarithm of the return index. S.MK.RET is the median annual return of the FTSE-350 share index. L.MK.RET is the median three year return of the FTSE-350 share index. S.IN.RET is the median annual return of the FTSE-350 share sector index. L.IN.RET is the median three year return of the FTSE-350 share sector index. SALES are the natural logarithm of company sales. *Correlation is significant at better than the $5 \%$ level (two-tailed). ${ }^{* *}$ Correlation is significant at better than the $1 \%$ level (two-tailed). 
Table 3

Chief executive basic pay $(\mathrm{BP})^{\mathrm{a}}$, fixed effects regression on short-term performance

\begin{tabular}{|c|c|c|c|c|c|c|}
\hline Variable & Model $1.1^{\mathrm{a}}$ & Model $1.2^{\mathrm{a}}$ & Model $1.3^{\mathrm{a}}$ & Model $1.4^{\mathrm{a}}$ & Model $1.5^{\mathrm{a}}$ & Model $1.6^{\mathrm{a}}$ \\
\hline S.EPS $_{t-1}$ & $\begin{array}{l}-0.007 \\
(-0.44)\end{array}$ & & $\begin{array}{l}-0.012 \\
(-0.69)\end{array}$ & & & $\begin{array}{l}-0.014 \\
(-0.77)\end{array}$ \\
\hline S.RET ${ }_{t-1}$ & & $\begin{array}{l}0.011 \\
(1.18)\end{array}$ & $\begin{array}{l}0.012 \\
(1.25)\end{array}$ & $\begin{array}{l}0.023^{*} \\
(1.84)\end{array}$ & $\begin{array}{l}0.024^{* *} \\
(2.06)\end{array}$ & $\begin{array}{l}0.028^{* *} \\
(2.19)\end{array}$ \\
\hline S.IN.RET ${ }_{t-1}$ & & & & $\begin{array}{l}-0.040 * * \\
(-2.09)\end{array}$ & & $\begin{array}{l}-0.014 \\
(-0.52)\end{array}$ \\
\hline S.MK.RET ${ }_{\mathrm{t}-1}$ & & & & & $\begin{array}{l}-0.060 * * * \\
(-2.99)\end{array}$ & $\begin{array}{l}-0.050 \\
(-1.58)\end{array}$ \\
\hline $\operatorname{SALES}_{\mathrm{t}-1}^{\mathrm{a}}$ & $\begin{array}{l}0.099 * * * \\
(3.69)\end{array}$ & $\begin{array}{l}0.098 * * * \\
(3.70)\end{array}$ & $\begin{array}{l}0.099 * * * \\
(3.69)\end{array}$ & $\begin{array}{l}0.097^{* * *} \\
(3.67)\end{array}$ & $\begin{array}{l}0.096 * * * \\
(3.69)\end{array}$ & $\begin{array}{l}0.097^{* * *} \\
(3.67)\end{array}$ \\
\hline Intercept & $\begin{array}{l}11.521^{* * *} \\
(31.06)\end{array}$ & $\begin{array}{l}11.541^{* * *} \\
(31.65)\end{array}$ & $\begin{array}{l}11.528^{* * *} \\
(31.24)\end{array}$ & $\begin{array}{l}11.551^{* * *} \\
(31.70)\end{array}$ & $\begin{array}{l}11.559 * * * \\
(32.00)\end{array}$ & $\begin{array}{l}11.544^{* * *} \\
(31.56)\end{array}$ \\
\hline F-test & $\begin{array}{l}86.33 \\
(p<0.001)\end{array}$ & $\begin{array}{l}90.94 \\
(p<0.001)\end{array}$ & $\begin{array}{l}77.66 \\
(p<0.001)\end{array}$ & $\begin{array}{l}78.39 \\
(p<0.001)\end{array}$ & $\begin{array}{l}78.67 \\
(p<0.001)\end{array}$ & $\begin{array}{l}61.03 \\
(p<0.001)\end{array}$ \\
\hline $\mathbf{R}^{2}$ within & 0.679 & 0.680 & 0.680 & 0.682 & 0.683 & 0.684 \\
\hline $\mathbf{R}^{2}$ between & 0.566 & 0.562 & 0.563 & 0.558 & 0.557 & 0.558 \\
\hline $\mathbf{R}^{2}$ overall & 0.562 & 0.559 & 0.560 & 0.555 & 0.554 & 0.554 \\
\hline Observations & 833 & 833 & 833 & 833 & 833 & 833 \\
\hline
\end{tabular}

This table reports fixed effects regressions clustered by year and CEO-firm pair with robust standard errors. BP is annual basic pay. S.EPS is earnings per share. S.RET is the annual change in the natural logarithm of the return index. S.IN.RET is the median annual return of the FTSE-350 share sector index. S.MK.RET is the median annual return of the FTSE-350 share index. SALES are the natural logarithm of total company sales. Year dummy variables are included but not reported. t-statistics are in parentheses. *significant at better than the $10 \%$ level. ${ }^{* *}$ significant at better than the $5 \%$ level. ${ }^{* * *}$ significant at better than the $1 \%$ level. ${ }^{a}$ variable in natural logarithms. 
Table 4

Chief executive short-term PRP ${ }^{a}$, fixed effects regression on short-term performance

\begin{tabular}{|c|c|c|c|c|c|c|}
\hline Variable & Model $2.1^{\mathrm{a}}$ & Model $2.2^{\mathrm{a}}$ & Model $2.3^{\mathrm{a}}$ & Model $2.4^{\mathrm{a}}$ & Model $2.5^{\mathrm{a}}$ & Model $2.6^{\mathrm{a}}$ \\
\hline S.EPS & $\begin{array}{l}1.111 \\
(1.38)\end{array}$ & & $\begin{array}{l}0.881 \\
(1.26)\end{array}$ & & & $\begin{array}{l}0.752 \\
(1.11)\end{array}$ \\
\hline S.RET $T_{t}$ & & $\begin{array}{l}1.441^{* *} \\
(2.31)\end{array}$ & $\begin{array}{l}1.333^{* *} \\
(2.16)\end{array}$ & $\begin{array}{l}1.734^{* *} \\
(2.22)\end{array}$ & $\begin{array}{l}2.097^{* * *} \\
(2.85)\end{array}$ & $\begin{array}{l}1.842^{* * *} \\
(2.38)\end{array}$ \\
\hline S.IN.RET & & & & $\begin{array}{l}-0.881 \\
(-0.76)\end{array}$ & & $\begin{array}{l}1.010 \\
(0.75)\end{array}$ \\
\hline S.MK.RET & & & & & $\begin{array}{l}-2.800 * * \\
(-2.24)\end{array}$ & $\begin{array}{l}-3.540 * * \\
(-2.30)\end{array}$ \\
\hline $\operatorname{SALES}_{\mathrm{t}-1}^{\mathrm{a}}$ & $\begin{array}{l}-0.404 \\
(-0.63)\end{array}$ & $\begin{array}{l}-0.191 \\
(-0.32)\end{array}$ & $\begin{array}{l}-0.241 \\
(-0.40)\end{array}$ & $\begin{array}{l}-0.137 \\
(-0.22)\end{array}$ & $\begin{array}{l}-0.211 \\
(-0.36)\end{array}$ & $\begin{array}{l}-0.321 \\
(-0.54)\end{array}$ \\
\hline Intercept & $\begin{array}{l}16.171^{*} \\
(1.85)\end{array}$ & $\begin{array}{l}13.296 \\
(1.61)\end{array}$ & $\begin{array}{l}13.847^{*} \\
(1.67)\end{array}$ & $\begin{array}{l}12.600 \\
(1.51)\end{array}$ & $\begin{array}{l}13.789 * \\
(1.74)\end{array}$ & $\begin{array}{l}15.187^{*} \\
(1.88)\end{array}$ \\
\hline F-test & $\begin{array}{l}3.52 \\
(p=0.002)\end{array}$ & $\begin{array}{l}4.43 \\
(p<0.001)\end{array}$ & $\begin{array}{l}4.20 \\
(p<0.001)\end{array}$ & $\begin{array}{l}4.08 \\
(p<0.001)\end{array}$ & $\begin{array}{l}4.62 \\
(p<0.001)\end{array}$ & $\begin{array}{l}3.77 \\
(p<0.001)\end{array}$ \\
\hline $\mathrm{R}^{2}$ within & 0.057 & 0.072 & 0.079 & 0.074 & 0.086 & 0.093 \\
\hline $\mathrm{R}^{2}$ between & 0.014 & 0.027 & 0.052 & 0.041 & 0.025 & 0.030 \\
\hline $\mathrm{R}^{2}$ overall & 0.016 & 0.033 & 0.047 & 0.042 & 0.036 & 0.039 \\
\hline Observations & 855 & 855 & 855 & 855 & 855 & 855 \\
\hline
\end{tabular}

This table reports fixed effects regressions clustered by year and CEO-firm pair with robust standard errors. Short-term PRP is the cash value of paid annual bonus (including guaranteed deferred bonus compensation [paid in cash, options or shares] without additional performance conditions). Includes zeros for when minimum performance conditions have not been satisfied. S.EPS is earnings per share. S.RET is the annual change in the natural logarithm of the return index. S.IN.RET is the median annual return of the FTSE-350 share sector index. S.MK.RET is the median annual return of the FTSE-350 share index. SALES are the natural logarithm of total company sales. Year dummy variables are included but not reported. t-statistics are in parentheses. ${ }^{*}$ significant at better than the $10 \%$ level. ${ }^{* *}$ significant at better than the $5 \%$ level. ${ }^{* * *}$ significant at better than the $1 \%$ level. ${ }^{a}$ variable in natural logarithms. 
Farmer, M. A., Alexandrou, G., Archbold, S., 2010

Table 5

Chief executive long-term PRP ${ }^{\mathrm{a}}$, fixed effects regression on long-term performance

\begin{tabular}{|c|c|c|c|c|}
\hline Variable & Model $3.1^{a}$ & Model $3.2^{a}$ & Model $3.3^{a}$ & Model $3.4^{\mathrm{a}}$ \\
\hline L. RET $\mathrm{t}_{\mathrm{t}-1}$ & $\begin{array}{l}1.726^{* * * *} \\
(3.18)\end{array}$ & $\begin{array}{l}2.369 * * * \\
(3.70)\end{array}$ & $\begin{array}{l}1.879 * * * \\
(3.04)\end{array}$ & $\begin{array}{l}2.353^{* * *} \\
(3.67)\end{array}$ \\
\hline L.IN.RET $T_{\mathrm{t}-1}$ & & $\begin{array}{l}-2.023^{* *} \\
(-2.29)\end{array}$ & & $\begin{array}{l}-2.152^{* *} \\
(-2.13)\end{array}$ \\
\hline L.MK.RET & & & $\begin{array}{l}-1.068 \\
(-0.76)\end{array}$ & $\begin{array}{l}0.399 \\
(0.25)\end{array}$ \\
\hline SALES $_{t-1}^{a}$ & $\begin{array}{l}1.461 \\
(1.16)\end{array}$ & $\begin{array}{l}1.607 \\
(1.28)\end{array}$ & $\begin{array}{l}1.429 \\
(1.15)\end{array}$ & $\begin{array}{l}1.628 \\
(1.27)\end{array}$ \\
\hline Intercept & $\begin{array}{l}-10.024 \\
(-0.57)\end{array}$ & $\begin{array}{l}-12.000 \\
(-0.69)\end{array}$ & $\begin{array}{l}-9.499 \\
(-0.55)\end{array}$ & $\begin{array}{l}-12.323 \\
(-0.69)\end{array}$ \\
\hline F-test & $\begin{array}{l}5.05 \\
(p<0.001)\end{array}$ & $\begin{array}{l}5.02 \\
(p<0.001)\end{array}$ & $\begin{array}{l}4.33 \\
(p<0.001)\end{array}$ & $\begin{array}{l}4.46 \\
(p<0.001)\end{array}$ \\
\hline $\mathrm{R}^{2}$ within & 0.106 & 0.117 & 0.107 & 0.118 \\
\hline $\mathrm{R}^{2}$ between & 0.076 & 0.081 & 0.083 & 0.079 \\
\hline $\mathrm{R}^{2}$ overall & 0.081 & 0.087 & 0.086 & 0.086 \\
\hline Observations & 466 & 466 & 466 & 466 \\
\hline
\end{tabular}

This table reports fixed effects regressions clustered by year and CEO-firm pair with robust standard errors. Long-term PRP is the cash value of performance-options vesting in the current year, plus performance-shares vesting in the current year, plus long-term cash plan vesting in the current year, plus the grant value of time-vesting options, plus the grant value of time-vesting shares. Includes zeros for when minimum performance conditions have not been satisfied. L.RET is the three year change in the natural logarithm of the return index. L.IN.RET is the median three year return of the FTSE-350 share sector index. L.MK.RET is the median three year return of the FTSE350 share index. SALES are the natural logarithm of total company sales. Year dummy variables are included but not reported. t-statistics are in parentheses. *significant at better than the $10 \%$ level. ${ }^{* *}$ significant at better than the $5 \%$ level. ${ }^{* * *}$ significant at better than the $1 \%$ level. ${ }^{a}$ variable in natural logarithms. 
Table 6

Chief executive total PRPa ${ }^{a}$, fixed effects regression on short-term performance

\begin{tabular}{|c|c|c|c|c|c|c|}
\hline Variable & $\begin{array}{l}\text { Model } \\
4.1(S)^{a}\end{array}$ & $\begin{array}{l}\text { Model } \\
4.2(S)^{a}\end{array}$ & $\begin{array}{l}\text { Model } \\
4.3(S)^{a}\end{array}$ & $\begin{array}{l}\text { Model } \\
4.4(S)^{a}\end{array}$ & $\begin{array}{l}\text { Model } \\
4.5(S)^{a}\end{array}$ & $\begin{array}{l}\text { Model } \\
4.6(S)^{a}\end{array}$ \\
\hline S.EPS & $\begin{array}{l}0.000 \\
(0.00)\end{array}$ & & $\begin{array}{l}0.002 \\
(0.02)\end{array}$ & & & $\begin{array}{l}-0.013 \\
(-0.11)\end{array}$ \\
\hline S.RET $t$ & & $\begin{array}{l}-0.010 \\
(-0.25)\end{array}$ & $\begin{array}{l}-0.010 \\
(-0.25)\end{array}$ & $\begin{array}{l}0.057 \\
(1.14)\end{array}$ & $\begin{array}{l}0.085^{*} \\
(1.90)\end{array}$ & $\begin{array}{l}0.081 \\
(1.64)\end{array}$ \\
\hline S.IN.RET & & & & $\begin{array}{l}-0.198^{* *} \\
(-2.21)\end{array}$ & & $\begin{array}{l}0.051 \\
(0.44)\end{array}$ \\
\hline S.MK.RET & & & & & $\begin{array}{l}-0.402^{* * *} \\
(-3.70)\end{array}$ & $\begin{array}{l}-0.446^{* * *} \\
(-3.08)\end{array}$ \\
\hline SALES $^{a}{ }_{t-1}$ & $\begin{array}{l}0.306^{* * * *} \\
(2.87)\end{array}$ & $\begin{array}{l}0.304^{* * *} \\
(2.87)\end{array}$ & $\begin{array}{l}0.304^{* * *} \\
(2.87)\end{array}$ & $\begin{array}{l}0.315^{* * *} \\
(3.01)\end{array}$ & $\begin{array}{l}0.301^{* * *} \\
(2.86)\end{array}$ & $\begin{array}{l}0.298^{* * *} \\
(2.86)\end{array}$ \\
\hline Intercept & $\begin{array}{l}9.346 * * * \\
(6.36)\end{array}$ & $\begin{array}{l}9.364 * * * \\
(6.40)\end{array}$ & $\begin{array}{l}9.366^{* * *} \\
(6.40)\end{array}$ & $\begin{array}{l}9.220 * * * \\
(6.38)\end{array}$ & $\begin{array}{l}9.442^{* * *} \\
(6.50)\end{array}$ & $\begin{array}{l}9.479 * * * \\
(6.58)\end{array}$ \\
\hline F-test & $\begin{array}{l}45.95 \\
(p<0.001)\end{array}$ & $\begin{array}{l}46.12 \\
(p<0.001)\end{array}$ & $\begin{array}{l}39.54 \\
(p<0.001)\end{array}$ & $\begin{array}{l}42.78 \\
(p<0.001)\end{array}$ & $\begin{array}{l}46.23 \\
(p<0.001)\end{array}$ & $\begin{array}{l}36.25 \\
(p<0.001)\end{array}$ \\
\hline $\mathrm{R}^{2}$ within & 0.417 & 0.417 & 0.417 & 0.422 & 0.431 & 0.431 \\
\hline$R^{2}$ between & 0.390 & 0.389 & 0.389 & 0.388 & 0.385 & 0.383 \\
\hline $\mathrm{R}^{2}$ overall & 0.413 & 0.412 & 0.413 & 0.411 & 0.413 & 0.412 \\
\hline Observations & 861 & 861 & 861 & 861 & 861 & 861 \\
\hline
\end{tabular}

This table reports fixed effects regressions clustered by year and CEO-firm pair with robust standard errors. Total PRP is the sum of basic pay, plus other cash, plus short-term performance-realised pay, plus long-term performance-realised pay. S.EPS is earnings per share. S.RET is the annual change in the natural logarithm of the return index. S.IN.RET is the median annual return of the FTSE-350 share sector index. S.MK.RET is the median annual return of the FTSE-350 share index. SALES are the natural logarithm of total company sales. Year dummy variables are included but not reported. $\mathrm{t}$-statistics are in parentheses. ${ }^{*}$ significant at better than the $10 \%$ level. ${ }^{* *}$ significant at better than the $5 \%$ level. ${ }^{* * *}$ significant at better than the $1 \%$ level. ${ }^{a}$ variable in natural logarithms. 
Table 7

Chief executive total PRP ${ }^{\text {a }}$, fixed effects regression on long-term performance

\begin{tabular}{|c|c|c|c|c|}
\hline Variable & Model 4.1(L) & Model 4.2(L) & Model 4.3(L) ${ }^{\mathrm{a}}$ & Model 4.4(L) ${ }^{a}$ \\
\hline L.RET $\mathrm{t}-1_{1}$ & $\begin{array}{l}0.114^{* * *} \\
(3.37)\end{array}$ & $\begin{array}{l}0.120 * * * \\
(2.90)\end{array}$ & $\begin{array}{l}0.116^{* * *} \\
(3.15)\end{array}$ & $\begin{array}{l}0.120 * * * \\
(2.89)\end{array}$ \\
\hline L.IN.RET ${ }_{\mathrm{t}-1}$ & & $\begin{array}{l}-0.020 \\
(-0.35)\end{array}$ & & $\begin{array}{l}-0.020 \\
(0.08)\end{array}$ \\
\hline L.MK.RET ${ }_{\mathrm{t}-1}$ & & & $\begin{array}{l}-0.015 \\
(-0.16)\end{array}$ & $\begin{array}{l}0.001 \\
(0.00)\end{array}$ \\
\hline SALES $^{a}{ }_{t-1}$ & $\begin{array}{l}0.245^{* *} \\
(2.66)\end{array}$ & $\begin{array}{l}0.246^{* * *} \\
(2.68)\end{array}$ & $\begin{array}{l}0.245^{* * *} \\
(2.66)\end{array}$ & $\begin{array}{l}0.246^{* * *} \\
(2.68)\end{array}$ \\
\hline Intercept & $\begin{array}{l}10.190 * * * \\
(8.00)\end{array}$ & $\begin{array}{l}10.174^{* * *} \\
(7.99)\end{array}$ & $\begin{array}{l}10.194^{* * *} \\
(8.02)\end{array}$ & $\begin{array}{l}10.174^{* * *} \\
(8.00)\end{array}$ \\
\hline F-test & $\begin{array}{l}46.85 \\
(p<0.001)\end{array}$ & $\begin{array}{l}40.26 \\
(p<0.001)\end{array}$ & $\begin{array}{l}40.45 \\
(p<0.001)\end{array}$ & $\begin{array}{l}35.38 \\
(p<0.001)\end{array}$ \\
\hline $\mathrm{R}^{2}$ within & 0.431 & 0.431 & 0.431 & 0.431 \\
\hline $\mathrm{R}^{2}$ between & 0.430 & 0.429 & 0.430 & 0.429 \\
\hline $\mathrm{R}^{2}$ overall & 0.444 & 0.443 & 0.444 & 0.443 \\
\hline Observations & 786 & 786 & 786 & 786 \\
\hline
\end{tabular}

This table reports fixed effects regressions clustered by year and CEO-firm pair with robust standard errors. Total PRP is the sum of basic pay, plus other cash, plus short-term performance-realised pay, plus long-term performance-realised pay. L.RET is the three year change in the natural logarithm of the return index. L.IN.RET is the median three year return of the FTSE-350 share sector index. L.MK.RET is the median three year return of the FTSE-350 share index. SALES are the natural logarithm of total company sales. Year dummy variables are included but not reported. $t$-statistics are in parentheses. ${ }^{*}$ significant at better than the $10 \%$ level. ${ }^{* *}$ significant at better than the $5 \%$ level. ${ }^{* * *}$ significant at better than the $1 \%$ level. ${ }^{\text {a }}$ variable in natural logarithms. 